\title{
The Post-Brexit Declaration on Social Quality in Europe
}

\author{
Alan Walker* and Steve Corbett** \\ * Department of Sociological Studies, University of Sheffield \\ E-mail: a.c.walker@sheffield.ac.uk \\ **School of Social Sciences, Liverpool Hope University \\ E-mail: corbets@hope.ac.uk
}

Twenty years ago, at a public ceremony in Amsterdam, a group of European academics made a solemn declaration on the future of the European Union (EU). Eventually over 1000 scholars and policy makers signed the Amsterdam Declaration on the Social Quality of Europe and it was translated into sixteen languages. The main intention behind the declaration was to remind policy makers and citizens about the unique nature of the western European model of development, comprising aspirations for economic growth, competitiveness and social justice. The risk being warned against was that, in the process of Economic and Monetary Union, the politics of integration would neglect what was then labelled the 'social dimension' and, among other far-reaching consequences, this would lead to a loss of legitimacy for the whole European project. As the Comite des Sages put it, bluntly, in 1996, 'Europe will be a Europe for everyone, for all its citizens, or it will be nothing'.

The Declaration called for a European society that is economically successful, but which also promotes social justice and full citizenship for all. This would be a Europe in which social quality for all was paramount rather than elite interests. Social quality was formulated as a potential counter-weight to the then growing, rather than now dominant, neoliberal hegemony of narrow economism to express the fundamental importance of social relations to all human life. It is defined as the extent to which people are able to participate in the social, economic and cultural life of their communities and countries under conditions that enhance their well-being and individual potential. To do so they must have access to life enhancing levels of socio-economic security, experience social inclusion in all groups and organisations, live in a socially cohesive context and be empowered to reach their full potential. Despite initial enthusiastic acceptance within the European Commission and its export to several Asian countries, the concept has not taken root in Europe. This may help to explain the present deep crisis of legitimacy facing the EU.

Now the urgent need is not to look back but forward. Four critical overlapping developments call for a renewal of the Declaration made in 1997. First, the unheeded warnings have come to fruition. In particular neoliberalism has encouraged inequality to grow exponentially and is now the biggest threat to democracy, as the Pope and President Obama among others have pointed out. Today the eight richest people in the world hold the same wealth as the 3.6 billion poorest people. In 2010 it was the 388 richest people. Oxfam estimates that by 2030 an additional 200 million people will live in unnecessary extreme poverty. Second, the European migration crisis caused by war 
and poverty in Africa has presented the EU with stark moral and economic challenges. For some countries, such as the UK, EU enlargement coupled with free movement of labour led to additional problems, notably racism and xenophobia. Third, the urgency of the need for action on climate change has reached crisis level so that now the societal and environmental futures of Europe are inextricably bound together. Fourth, there is the rapid rise of populist nationalism across Europe, which contributed to the UK's Brexit vote and the political rise of Donald Trump in the US (a phenomenon Trump dubbed 'Brexit plus plus plus'). But combatting crude nationalism was one of the compelling reasons for the creation of the EU in the first place. The unprecedented Brexit decision should provide a severe jolt to those EU leaders who failed to heed earlier warnings about the need for an inclusive Europe. Without a radical change in direction, the UK is a lost cause for the EU but, elsewhere, there is still time to regenerate and refocus the European project.

\section{Brexit and President Trump}

Although Brexit was a largely British-made phenomenon the EU itself cannot escape some of the blame. It ignored the warnings against sacrificing the 'social dimension' on the altar of neoliberalism and, instead, promoted a variant of the long discredited 'trickle-down' economics. True to its utilitarian roots, neoliberalism argued that free trade would solve the problems of poverty and social exclusion. Taken to its extreme in the TTIP Europe would forgo its right to societal regulation in key areas such as minimum wages and food safety. In short the interests of European citizens were forfeited to those of the corporations and the hyper-elite 0.1 per cent. So, in the UK's referendum campaign the only case made against Brexit was a negative one about the dire economic consequences, the politics of fear. Little wonder that those excluded or marginalised by decades of neoliberal driven policies, culminating in austerity, saw nothing to commend remaining in the EU. Instead there was an opportunity to rage against the liberal elite with the EU as a scapegoat, an open goal if ever there was one. The scapegoat was successfully set up by years of anti-EU propaganda by the right-wing press (which was never challenged consistently by political leaders), which contributed to the creation of the UK Independence Party, formed specifically to campaign for exit from the EU.

For its part the Remain campaign had nothing positive to say about how, for example, European social solidarity could help to overcome exclusion and marginalisation, only that more free trade and deregulation would benefit all. It was the single market that was their sole focus. No-one spoke specifically to or for the excluded and the communities destroyed by de-industrialisation, although the highly negative portrayal of the EU in the British press and lukewarm support for it among English political leaders was so entrenched that it would have been hard to reverse it in a short campaign. Thus Brexit should not be interpreted as a vote against any specific policy or trade deal; rather, for many it was a rejection of the consequences of neoliberalism and the perception that the EU promotes corporate above individual interests, is remote from everyday life and uninterested in those excluded by globalisation.

Some will plead British exceptionalism but the Brexit vote, albeit a close one, chimes with both the recent US election and the rise of right-wing populist nationalism in several other EU countries. The common threads are: 
- The exponential growth of inequality in incomes and wealth, especially housing wealth.

- The transformation of universal social security into residual welfare via the hollowing out of the welfare state and the undermining of social solidarity.

- The ever deepening fault lines between the securely employed (and pensioned), the precarious (just scraping by) and the totally excluded; between the comfortable and the severely deprived; between generations facing very different economic prospects; and between different ethnic minority groups.

- The run-down, neglect and abandonment of communities in once prosperous industrial areas.

- The abject mismanagement of migration resulting in the encouragement of xenophobia and racism and the failure of political leaders to stand up for common humanity.

- The detachment of a liberal ruling political elite from any contact with or understanding of ordinary everyday lives.

- The challenge to democracy created by the spread of individualism in the atomised world of social media.

In short, in many EU countries led by the UK and at EU level in Brussels, a narrow utilitarian neoliberal policy agenda has taken root across the political spectrum with devastating societal, economic and environmental consequences. The last straw was the imposition of austerity on the many following the financial crash caused by an elite few, who escaped unscathed. This came on top of decades of increasing neo-liberal policy hegemony which, at best, severely limited the scope for political action under the banner of TINA (there is no alternative). The predictable result is that the effectively disenfranchised turn to those offering alternatives, albeit bogus ones. In Trump's case history repeats itself as farce, although it may end in tragedy.

\section{The new politics}

As in the US a politics that rejects change from the social democratic left and attempts to humanise neoliberalism, while failing to take inequality seriously (Obama with Clinton offering more of the same), only succeeds in contributing to the deeper embedding of neoliberalism. In doing so the liberal elite stokes alienation and class anger, along with victim blaming, xenophobia and racism, and paves the path for authoritarian populist economic and social nationalists such as Trump. Thus it is not populism per se that is the problem, as some have suggested, but only when it takes xenophobic, 'post-truth' and demagogic forms. Populism espousing participative democracy, respect, equality and social inclusion for all would be welcome.

The new normal politics is marked by anger: anger at disconnected and gilded technocratic and political elites, anger at the privatisation of profit and socialisation of risk for financial institutions and major corporations, and anger at the perceived preferences given to some groups over others. The kind of politics developing in the early twenty-first century is increasingly defined not by variants of conservatism, socialism, and liberalism, and their respective alternate visions of an ideal society played out in democratic politics, but by divisions of openness against closure; economic competition against division and exclusion; technocratic economism against 'post-truth' ideologies in which anything goes. In these emergent divisions, the victims are solidarity, cooperation, and social and economic justice, and the human cost to the social quality of millions 
of people's lives. Neither the neoliberal or new proto-nationalist and fascist directions offer a sound future, but reflect the legacy of Machiavelli and Hobbes' philosophies based on greed and individual selfishness that accentuate absolute power, struggle, competition, rivalry, and envy. What is required is a different politics that reflects the principles in the original Amsterdam Declaration and reformulated here: social justice and the equitable participation of citizens in societies that are sustainable, fair, inclusive, open and economically vibrant.

\section{The urgent need for social quality}

A Europe that was forged to keep peace between its warring nations and subsequently to encourage and support societal development and cooperation has increasingly given way to a slavish pursuit of economic competition and the vast inequalities in income, wealth, and societal standing that result from this. Alongside this has been the development of a precarious Europe, not built around security and opportunity for all of its citizens, but by a race to the bottom in weakening workers' rights and reducing the opportunities for people to enjoy a dignified, secure and prosperous life. The growing precariat in major cities and rural areas - along with the reduction of secure housing, lifelong educational opportunities, and well-paid jobs - for many are sources of popular anger. European policy makers must also recognise that when public services are hollowed out and sold off to private companies and trade agreements propose to further increase the power of multinational corporations against their citizens, people increasingly recognise injustice and unfairness in the direction of international institutions and within many EU member states. The promotion of individualistic consumerism and vulgar materialism as a way of life at the expense of participation - in neighbourhoods, schools, community organisations, economic and political organisations as part of the sociality of human life - is a source too of the disconnection and disaffection that many people feel.

We see also the return of absolute poverty, nineteenth century illnesses, and homelessness in the streets of major cities, those urban areas in which very soon 75 per cent of the world's population will live. Challenges to the EU project of peace and cooperation stem also from policy decisions and war, in which we see the swelling pressure of migrants and refugees living in unbearable circumstances or without basic human rights and hope of a better life. Finally, the looming catastrophic consequences of climate change, its exacerbation of the above issues and threat to the long-term survival of the human race. Despite some movement on the issue with the Paris Agreement, which suggests the possibility of global cooperation today, at present 129 Nation States out of 198 have ratified the convention.

Why is social quality an important part of the answer? First, because it requires us to re-focus on, and re-think, the concept of 'the social' in a systematic way. Thus it goes beyond eclectic concepts such as social capital, quality of life, happiness and human development. This injunction emphasises the need for a theoretically grounded response to neoliberal economism. In view of the multiple societal and existential crises confronting Europe, a comprehensive conceptualisation is needed urgently. A key problem is that European and national discourses are characterised by the indiscriminate use of the term 'social dimension' when no-one is sure what exactly the 'social' means. By failing to define it clearly, false dichotomies are produced, notably between the economic and 
the social and between the environmental and the social. In particular the first false dichotomy has bedevilled European discourses and facilitated the neoliberal take over of policy. By ignoring the social nature of human beings and their complex motivations, a very limited idea of human nature has been allowed to dominate policy and politics: the mechanistically calculating individual in pursuit of their material interests - homo economicus. The massive evidence of major non-materialistic motivations, such as kinship, love, duty, morality and coercion, has not prevented a socially-blind model of human behaviour from achieving ascendancy. Occasional laments for the 'loss of community' may be interpreted as a loss of the social, and with it, the normative concepts of equality, justice and fairness. The false dichotomy between the economic and social and neo-liberal reduction have prevented a clear articulation of the constitutional interdependency of the social, including the political, the cultural, the economic and the environmental. In contrast social quality starts by defining the social: the interrelated relations of production and reproduction between people, which are constituted by a combination of processes of self-realisation and the formation of collective identities. This means that, second, economic relations are but one aspect of wider societal relations because they entail social production and reproduction. The recognition of this means that the combination of economic and social policy could lead to genuine measurable inclusivity that transforms, rather than humanises, capitalism. Third, social quality is not simply an intellectual product but also has the practical goal to empower citizens in its pursuit. It proposes a political programme to change society.

\section{Declaration}

Respect for the fundamental human dignity of all citizens and our shared humanity requires us to declare that poverty, homelessness or housing stress, poorly paid employment, unemployment, exploitation and social exclusion should not be witnessed in modern day Europe. The fact that these fundamental problems still exist and are growing, and the shameful response of many authorities to the migrant crisis, emphasise the distance Europe has to go to ensure social quality for all.

We want, in contrast, a Europe that is economically successful but which, at the same time, promotes social justice and participation for all. This would be a Europe in which social quality is paramount. Its citizens would be able to fully participate in the lives of their communities and countries and to do so in ways that enhance their wellbeing, their individual potential and overall societal development. In a globalised world, competitiveness should go hand in hand with the promotion of socio-economic security, social cohesion, social inclusion, social empowerment and sustainability. Not only is it vital for Europe to ensure that every citizen realises their full potential but, also, those forced to flee their homeland must be treated with the common humanity that has been a recurring theme of centuries of European discourse: Homo sum, humani nihil a me alienum puto. 'I am human, I think nothing human alien to me'.

Social quality requires the following basic conditions:

- Personal and family security and protection from violence and ecological threats;

- Clean air and water, and the expectation of an environmentally sustainable future;

- Decent housing, heating, clothing and nutritious food for all;

- Quick access to universal health care and social services for those who need them; 
- An expectation that the state will encourage actions towards healthy lives and to prevent unnecessary disability;

- Fair work in terms of working conditions, equality of opportunity, pay, training, care leave and pensions;

- Sufficient work for all, including not only paid employment but also the non-paid activities upon which society depends;

- An income for all, whether through employment or social security, that allows full participation in society;

- Actively building social solidarity by ensuring that every citizen has sufficient income to contribute to public services through general taxation;

- An equitable tax system without loopholes for corporations and the rich;

- The opportunity for all to be integrated in the local communities and society they live in, regardless of age, race/ethnicity, gender or sexual orientation;

- Access to social protection systems which enable citizens to maintain, in solidarity, a reasonable standard of living in case of social contingencies; these social protection systems should focus first on the prevention of social risks and only then address their cure and, finally, their financial compensation;

- Lifelong access to education and training opportunities for all;

- The elimination of discrimination on the basis of nationality, age, gender, race, religion, political or other beliefs, marital status, and sexual orientation;

- Action to reduce regional disparities in income, wealth and life chances.

These aspects of social quality must be realised through the recognition of enforceable fundamental rights that are legally binding for all legislators, administrators and judges. These rights find their limits where the corresponding rights of others begin. They must also have due regard to the ecological context: sustainable social quality or a fair distribution of sustainable social quality.

Social quality in Europe requires that European citizens can reply upon a clear and effective distribution of responsibilities between the Union, the Members States and Local Authorities.

- To promote the interests of all citizens in a fair and open way;

- European citizens have a right to know who is politically responsible so that, if required, they can question inappropriate policies;

- Strengthening the democratic quality of political decision-making at all levels requires that, in this process, the input of social organisations and movements, as well as the active participation of citizens, are guaranteed;

- A globalised world requires that Europe acts in a socially responsible way towards the weakest and rejects a fortress mentality.

The European Union is urged:

- To make all major European policies subject to a social quality impact statement;

- To set up and disseminate the results of a study that shows the costs of not prioritising social quality;

- To draft clear measurable benchmarks for each social objective that figures in the EU legal documents that have been adopted so far with respect to social and environmental aspects and to report regularly on the degree to which these targets have been reached; 
- To engage in concerted bench-learning so that the most effective approaches to promoting social quality are encouraged in all Member States;

- To set a new agenda for the promotion of social quality in Europe, one that engages policy makers and citizens;

- To play a leading role in action to protect the planet, in the first instance by minimising further global warming.

In our capacity as responsible European citizens we solemnly declare that the European Union should urgently give priority to its social quality, otherwise it will lose further legitimacy and will not be the Union we support. This does not mean heavy topdown policy making but reasoned argument for the reversal of neoliberal-driven inequality and a more open, participative form of democracy. The rich variety of European nations must be maintained but membership of the Union should require an aspiration for social quality. This is essential if citizens of the Union are to realise their full potential and, in turn, support the continuation of the Union. (Likewise, on leaving the EU, the UK must recognise the folly of the Singapore-option (low tax, poor workers' rights and tax haven status) and must, on its own terms, aspire to European levels of social quality.) Social quality is fundamental to the creation of an inclusive Europe, a Europe for all citizens.

Alan Walker and Steve Corbett 